\title{
"To go abroad from Scotland..." \\ The South American Travel Diary of Thomas Wilson
}

\section{by Marc Richard}

\begin{abstract}
This paper describes an original typescript diary recently discovered in the collections of the McGill University Libraries. Written by an employee of a Scottish engineering firm on a business trip to South America in 1909 and 1910, it affords an intriguing glimpse into the Scottish presence in Latin America at the turn of the century.
\end{abstract}

\section{RESUMÉ}

Cet article décrit un manuscrit original dactylographié récemment découvert dans les collections des Bibliothèques de l'Université McGill. Rédigé par un employé d'une compagnie écossaise de génie en voyage d'affaire en Amérique du sud en 1909 et 1910, ce journal permet d'entrevoir la présence écossaise en Amérique latine à cette époque.

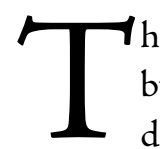

he social and economic influence exerted by Scots living abroad - the "Scottish diaspora" - and by Scottish overseas investment is a topic that has been attracting increased attention from scholars. Recent studies by Gordon T. Stewart ${ }^{1}$, Michael Fry ${ }^{2}$ and Arthur Herman $^{3}$ have examined in detail the considerable impact which Scots have had on the British Empire and other parts of the world. One region, however, where Scottish presence is infrequently noted is Latin America. This apparent absence is somewhat misleading. Manuel A. Fernandez points out that, while Latin America was not a primary destination for Scottish emigrants and investors, Scots' settlement in the region did noticeably increase in the second half of the 19th century. ${ }^{4}$ Fernandez attributes the scarcity of references to Scots to the historical fact that many Scottish enterprises in Latin America were established locally rather than in Scotland which resulted in their not being mentioned by standard financial sources - and to the tendency of older documents not to differentiate between the terms "Scottish," English" and "British."

In this context, contemporary primary sources that allow us to glimpse the presence of Scots in Latin America are of considerable interest. One such document was recently discovered in the McGill University Library: the unpublished travel diary of a Scotsman who made a business trip to various South American countries in 1909 and 1910. It surfaced as part of routine work being done by the Collection Services department to revise problematic cataloguing records and to give Library of Congress call numbers to the few remaining works shelved in the Library's Cutter classification section - the Cutter system having been employed by McGill between 1893 and 1967. The author of the present article noted a bound original typescript diary dating from the early 20th century and, therefore, a unique item of potential historical interest. It now resides in the McLennan Library's Rare Books and Special Collections Division, and this article has been 
prepared to describe the diary for interested scholars.

\section{THE DIARY AND ITS BACKGROUND}

The typescript is by Mr. Thomas Wilson, "Diary Written on First South American Tour: the Journey Occupying from 9th November, 1909 till 29th June, 1910," and consists of 262 singlesided, double-spaced typescript leaves, measuring $190 \mathrm{~cm} \times 260 \mathrm{~cm}^{6}$ The hardcover binding is dark blue, with marbled endpapers and goldcoloured edges; the author's name and a brief title are stamped in gold on the spine. The binding, which is fairly elaborate by McGill standards, along with the gilt page tops, suggests that the typescript would originally have been held by a private owner who donated it to McGill. Brief entries for the diary are contained in both the Library's accession book and shelflist, but without information on the provenance. Judging from the accession number, 512595, the diary would have been added to the collection in the early 1960s.

The diary appears to have been typed professionally: the page formatting is neat and the spelling accurate, with only a few corrections added in pen. It is likely, therefore, that the document was transcribed from a handwritten journal sometime after Wilson's return from South America rather than during the trip itself. The text is an actual journal, not a retrospective account, as shown by entries written in haste while the author was in transit, such as "I am finishing my reports upon this town, and will leave for Buenos Aires in the afternoon. Now I am en route for Buenos Aires, I have secured a sleeping compartment all for myself." (Wilson, 130)

Wilson appears to have prepared the diary simply for his own satisfaction, as it is without the biographical and other background information normally associated with a work meant for publication. Indeed no biographical information on Wilson has so far been located, other than the mention in his diary that his birthday fell on 1 April. (Wilson, 146) It has, however, been possible to deduce from other parts of the text and external sources where he worked and why he was traveling in South America.

Wilson was an employee of Loudon Brothers, (Wilson, 167) a firm which specialized in manufacturing special and general machine tools for engineers, boilermakers, shipbuilders and railway companies, both for domestic customers and export. ${ }^{7}$ The company dates back to at least 1875, when it purchased the firm of A. Macarthur $\&$ Son, located at the Clyde Engineering Works in Johnstone. These facilities were then greatly expanded to meet increased demand, including contracts from the British Admiralty. Around 1901, the firm built an office and warehouse facility in Glasgow, where Wilson appears to have been working at the time of his South American voyage. The purpose of his trip was to visit a number of railway-related businesses to secure orders for railway machine tools.

\section{WILSON'S ITINERARY}

Wilson set out by train from Glasgow to London and Southampton, where he boarded a passenger liner; the ship made stops in Spain, Portugal and Madeira, then crossed the Atlantic to Brazil. During the next few months, Wilson's business dealings took him to the following principal destinations:

- Brazil: Rio de Janeiro (including Niterói), São Paulo (including Jundiaí), Pernambuco, and São João del Rei

- Uruguay: Montevideo

- Argentina: Buenos Aires, Rosario, Córdoba, and Mendoza

+ Chile: Santiago, Valparaíso, and Concepción

+ Peru: Lima

Wilson's return journey was more circuitous than the outward trip, including stops in Panama 
City, Colón, Cartagena, Trinidad, Barbados, the Azores, Cherbourg and, finally, Southampton, from which he returned to Glasgow by train. The South American countries Wilson visited were, not surprisingly, the ones with the most extensively developed railway networks. Statistics compiled in $1892-93^{8}$ show that, at the end of the 19th century, the countries with the greatest length of track open to traffic were Argentina $(12,994 \mathrm{~km})$ and Brazil $(10,281 \mathrm{~km})$, followed more distantly by Chile $(2,824 \mathrm{~km})$, Uruguay $(1,602 \mathrm{~km})$ and Peru $(1,532 \mathrm{~km})$. Argentina's extensive and integrated rail system is particularly noteworthy. Built and owned almost entirely by the British, with the blessings of Argentinian leaders, ${ }^{9}$ it was then the tenth largest rail network in the world. ${ }^{10}$

\section{CONTENT AND STYLE}

In his diary, Wilson touched only briefly on business affairs, since these matters were covered in separate reports sent to his employer, although he did sometimes mention visits to particular railway companies or engineering works. Instead, he recorded impressions of the countries through which he was traveling, noted personal activities, related encounters with various fellowcountrymen and described what it was like to experience abroad newsworthy events, such as the death of King Edward VII. (Wilson, 189, 191, 209-210)

Wilson's writing is clear and literate, with well-articulated phrases and a somewhat formal style. On some occasions, he writes more casually and uses run-on sentences; at other times, he becomes almost poetic such as when admiring a magnificent landscape:

Nobody can have any idea of the impressiveness of the thoughts which came through the mind in such a place as this. It must be that the Creator of the world loved the beautiful, and still takes the highest pleasure in the perfection of everything that he has done, otherwise all this extravagance of forest and flower, mountains and rivers, would go without anything like a proper share of appreciation. (Wilson, 62-63)

It is apparent from Wilson's usually cheerful tone that he enjoyed his trip: He often comments on how lovely a particular day is, and remains generally unruffled by occasional difficulties. The entry for 18 May 1910, for instance, reveals Wilson's amusement with Lima's anticipating the end of the world:

It was prophesied that to-night at 9 oclock Halley's comet would come into collision with the earth, and bring an end to everything. The churches have been crowded with people praying and making confession, preparing for the crack of doom, but now it is 12 oclock and there is no sign of the calamity, so I will get off to bed. [...] It was supposed that the comet would strike the earth at 9 o'clock, and at that hour everything was quiet, and people all looked very frightened. I was out on the Plaza also, and about ten minutes past nine people began to talk a little, and look somewhat relieved, then about a quarter or twenty minutes past nine the crowds began melting away into the side streets. I retired at my usual time. There appeared in the morning a notice on the front page of the newspapers, that owing to the fervent and continual prayers of the church, the great catastrophe had been averted. So this was all the poor people got for their money, meanwhile the church had greatly profited by the incident. (Wilson, 205-206)

The comet nevertheless managed to give the normally unflappable Wilson a belated fright a few days later, in the wee hours of 21 May, when an earthquake woke him in his hotel bed."It gave us a very sudden shock, and rattled the furniture, and for a minute or two I did not know what had 
happened. At first I thought Halley's comet had arrived at last, but I lay still to see if anything else was going to happen." (Wilson, 212) In compensation for this rude awakening, Wilson later had at least two opportunities to admire the comet under excellent conditions during the first leg of his sea voyage back to Scotland. (Wilson, 221;223)

In relating such anecdotes, Wilson does so in a restrained, half-serious manner which tends to underscore the humour of the situation. During a stopover in Lisbon, for instance, Wilson and some companions "had lunch which cost 2.890 Milreis, and like Mark Twain we thought we were ruined, but it was not so much after all." (Wilson, 10) In another lunchtime incident, this time in Lima, Wilson relates that a policeman and several military personnel "arrested two men sitting at the table next to me. The men were just starting lunch, but they were allowed to finish, and then walked off with the Military. Later on in the day I heard they were released, they had been taken up on suspicion, as the policeman had seen them taking photographs. They found however, that it had been a mistake, and finally they put the policeman in prison for excess diligence -- a most unusual crime in this country." (Wilson, 198-199)

Wilson sometimes shows genuine annoyance at the mishaps he experienced during his travels. "My room is filthy," he complains during his stay in São Paulo. "I don't much care for the food which I get at the Grand Hotel, it is very badly cooked, the hotel is 'Grand' only in name and in prices." Later, finding himself in Valparaiso with only one small bag, he grumbles that, "My two large cabin trunks are at Santiago, and another trunk with all my business papers, as far as I can learn, is at Las Cuevas, on the other side of the Andes, notwithstanding that all were addressed to me in Valparaiso, that is how they handle baggage in Chile." (Wilson, 152) For the most part, however, Wilson's journey was reasonably free of hardship. His account of the sea crossing to Brazil is notable for the contrast between the many comforts to which he was entitled -- such as the services of a bath steward, ice cream treats served daily in the tropics, and dances held every evening (Wilson, 23-24) -. and the wretched conditions endured by Russian emigrants traveling in the ship's steerage section. (Wilson, $6 ; 10$ )

The diary includes a number of passages where Wilson proves to be a keen observer with a talent for recording technical information. Having a professional interest in railway machinery, he devotes two pages to the mechanisms which allow the train connecting São Paulo to Santos to negotiate a steep mountain range:

Those special engines are made with grippers which fasten on to endless ropes, to which the train is attached and by which it is hauled. [...] This locomotive is also fitted with a vacuum brake, which can stop it dead at any moment. It has also grips operated by steam power, so that in the case of an accident or interruption of the line, these grippers can hold the train fast to the rails. [... The journey down the Serra is made in five sections, so that five endless ropes are employed, there are five power stations, each with great station[a] ry hauling engines about 1,000 horse power, and ten trains are always running at the same time on the Serra. (Wilson, 69-70)

Even when describing subjects outside his area of expertise, Wilson shows similar attention to detail, as when he explains the process used to harvest sugarcane in Peru. (Wilson, 206-208) During a recreational outing on muleback in the Andes with some friends, Wilson notes with interest his physiological reactions to the high altitude. (Wilson, 144-145)

Although he expresses admiration for the engineering marvels he encounters, Wilson is mindful of the sacrifices they might entail. 
Traveling along Argentina's Transdine Railway, he notices "the numerous little wooden crosses, marking the place where the weary workers have been buried, who were engaged building this remarkable railway. The achievements of the engineers in this direction are wonderful, but in many cases they cost a very great number of human lives." (Wilson, 147) Later, while journeying overland alongside the stillincomplete Panama Canal, he likewise observes a "number of cemeteries, which are just open spaces of ground with hundreds of small wooden crosses," and reflects on the tremendous number of casualties to which they testify. (Wilson, 234)

\section{ENCOUNTERS WITH SCOTS}

During his stay in Rosario, Wilson muses, "It is very interesting to meet these Scotchmen at the head of so many affairs here. I have felt many a time 'Wha's like us'. Invariably too they are very nice men, with no affectation and who are agreeable to spend a bit of time with me." (Wilson, 125) Several of these encounters are mentioned in the diary, with varying amounts of detail. Some are merely brief references, e.g. "In the forenoon I was engaged with Mr. Martin, the manager of the Water-works, he is a Scotchman from Paisley, so we had a long talk about things concerning that famous town." (Wilson, 125) Others point to a significant Scottish presence in certain parts South America, such as when Wilson reports meeting the Secretary of the St. Andrews Society in Belgrano for dinner and a game of bridge. (Wilson, 91)

Some entries provide a brief but tantalizing inventory of the compatriots Wilson encountered, as in the following paragraph:

Talking about the Scotch people, I might mention it is a Scotchman who has charge of the largest bank here, a Mr. Muir of the London and Brazilian Bank. A Scotchman is works manager of the Paulista Railway Company, it is a Scotchman who is one of the chief engineers on the Serra, and a Scotchman[,] Macdonald, reads the lessons at the English Church on Sunday. I had a long talk at Mr. Speers' house about old times in Scotland, and I must send Mrs. Speers some book like Dean Ramsay's when I get back, as she is very much interested in this kind of literature (Wilson, 73).

An earlier diary reference to $\mathrm{Mr}$. and Mrs. Speers -- a rail line chief at São Paulo and his wife Katarina -- mentions that she "is a great admirer of the Scotch, her father and grandfather were both Scotch." (Wilson, 65) Later, in Valparaiso, Wilson has the pleasure of being introduced to a fellow Glaswegian, Charles Dick, with whom Wilson teams up successfully for a game of bridge against two Chileans. (Wilson, 165-166) In Santiago, he meets a "great Burns enthusiast" named McKerlie who quotes from memory lengthy passages for Wilson's enjoyment: "It is my first experience abroad of meeting with a real out and out Burns man, and as he said after he had repeated some very touching lines about the old country, that the Scotchman who could repeat these verses without the tears coming into his eyes, was not worthy to be called a Scotchman." (Wilson, 169-170)

Occasionally, Wilson provides insights into what motivated some Scots to settle in South America. Describing his visit to an up-to-date workshop in Jundiaí, he also mentions that, " $[\mathrm{t}]$ he shop manager is a Scotchman, Mr. Scott, from Glasgow, (Dubs and Coy's), and he has been out here 24 years; he has no desire to come home again. He considers the climate is perfect, he has a wife and seven sons, and seems to be quite happy." (Wilson, 72-73) This thumbnail sketch was provided of an expatriate Scot living in Rosario:

Then after dinner I went to the English Club, to meet Mr. Tom Ferguson, of the Central Cordoba Railway. We sat together talking till about 12 o'clock. 
He belongs to Glasgow, and spent his boyhood days in Queen's Crescent. $\mathrm{He}$ was in our Mr. Stuart's class in the Sunday School, in Mr. Cameron's Church, in Cambridge Street, and was acquainted with many people I know and interested to hear about them. $\mathrm{Mr}$. Ferguson came out here 14 years ago, broken down in health. He could not have lived at home, he had had pleurisy for eighteen months, and was practically played out. He thought he had come out to die, but now you could not find a healthier or stronger looking man anywhere, and he never has the least sign of anything wrong with him, so that is what climate can do. His father was a partner in the old firm of James Copland \& Co., Dobbies Loan, and lost his money when that firm failed (Wilson, 123-124).

Wilson, for his part, was happy enough to sail home after completing his business in South America, where he had secured a good number of orders - much to the satisfaction of his employer. He returned to Scotland feeling that his great journey had been well worth doing.

A few days before his ship arrived in Britain, Wilson reflected on the new perspectives he had gained: "When I saw the fog this morning, and felt the cold in the air, I wondered why people should be so much afraid to go abroad from Scotland, where we have such a trying climate, however, I suppose it is just that we are brought up to it, and we think it is best for us." (Wilson, 255) Although Wilson may have had no interest in settling overseas, his journey had revealed to him how many enterprising compatriots had extended a Scottish presence to the warmer and less foggy climes of South America.

\section{ACKNOWLEDGEMENTS}

The author wishes to thank Mrs. Ellison Bishop for her assistance and encouragement during the preparation of this article.

\section{ENDNOTES}

${ }^{1}$ Gordon T. Stewart, Jute and empire: the Calcutta jute wallahs and the landscapes of empire (Manchester: Manchester University Press, 1998).

2 Michael Fry, The Scottish empire (Phantassie: Tuckwell Press, 2002).

3 Arthur Herman, The Scottish Enlightenment: the Scots' invention of the modern world (London: Fourth Estate, 2003).

${ }^{4}$ Manuel A. Fernandez, "The Scots in Latin America: a survey," in The Scots abroad: labour, capital enterprise, 1750 1914 (London: Croom Helm, 1985), 233.

${ }^{5}$ Ibid., 221-222.

${ }^{6}$ Thomas Wilson, "Diary written on first South American Tour: the journey occupying from $9^{\text {th }}$ November, 1909 till 29 ${ }^{\text {th }}$ June, 1910." (Typescript). McGill University. Rare Books and Special Collections Division.

7 Local industries of Glasgow and the west of Scotland (Glasgow: Local Committee for the Meeting of the British Association, 1901), 47.

${ }^{8}$ Juan José Castro, Treatise on the South American railways and the great international lines (Montevideo: La Nación Steam Printing Office, 1893), 575.

${ }^{9}$ Winthrop R. Wright, British-owned railways in Argentina: their effect on economic nationalism, 1854-1948 (Austin: University of Texas Press, 1974), 4-5.

${ }^{10}$ Colin M. Lewis, British railways in Argentina, 1857-1914: a case study of foreign investment (London: Athlone Press, 1983), 5 . 